\title{
Isolation and identification of bioactive compounds in Andrographis paniculata (Chuanxinlian)
}

\author{
Wen-Wan Chao and Bi-Fong Lin*
}

\begin{abstract}
Andrographis paniculata (Burm. f.) Nees (Acanthaceae) is a medicinal plant used in many countries. Its major constituents are diterpenoids, flavonoids and polyphenols. Among the single compounds extracted from A. paniculata, andrographolide is the major one in terms of bioactive properties and abundance. Among the andrographolide analogues, 14-deoxy-11,12-didehydroandrographolide is immunostimulatory, anti-infective and anti-atherosclerotic; neoandrographolide is anti-inflammatory, anti-infective and anti-hepatotoxic; 14-deoxyandrographolide is immunomodulatory and anti-atherosclerotic. Among the less abundant compounds from A. paniculata, andrograpanin is both anti-inflammatory and anti-infective; 14-deoxy-14,15-dehydroandrographolide is antiinflammatory; isoandrographolide, 3,19-isopropylideneandrographolide and 14-acetylandrographolide are tumor suppressive; arabinogalactan proteins are anti-hepatotoxic. The four flavonoids from A. paniculata, namely 7-Omethylwogonin, apigenin, onysilin and 3,4-dicaffeoylquinic acid are anti-atherosclerotic.
\end{abstract}

\section{Background}

Andrographis paniculata (Burm. f.) Nees (Acanthaceae) (A. paniculata, Chuanxinlian), native to Taiwan, Mainland China and India, is a medicinal herb with an extremely bitter taste used to treat liver disorders, bowel complaints of children, colic pain, common cold and upper respiratory tract infection [1-3]. The aerial part of A. paniculata is commonly used in Chinese medicine. According to Chinese medicine theory, A. paniculata 'cools' and relieves internal heat, inflammation and pain and is used for detoxication [4-6].

The herb contains diterpenoids, flavonoids and polyphenols as the major bioactive components $[7,8]$. This article reviews the constituents and pharmacological properties of $A$. paniculata, including its chemical components, biological activities and possible mechanisms. The literature search was conducted in Pubmed database (1984-2010), focused on language literature in English. The keywords used were selected from andrographolide, A. paniculata and its compounds with bioactivities. In comparison with other Chinese medicinal herbs, this well

\footnotetext{
* Correspondence: bifong@ntu.edu.tw

1 Department of Biochemical Science and Technology, College of Life Science, National Taiwan University, Taipei 10617, Taiwan

Full list of author information is available at the end of the article
}

studied herb not only shows a wide variety of health benefits, but many bioactive compounds are also being identified. Furthermore, several derivatives have been semisynthesized to enhance their bioactivity than original compounds, suggesting a potential for drug development. The authors read more than 200 full articles and a total of 124 peer-reviewed papers focused on anti-inflammation, anti-cancer, immunomodulation, anti-infection, antihepatotoxicity, anti-atherosclerosis, anti-diabetes and anti-oxidation were selected for this review.

\section{Bioactive constituents}

Active compounds extracted with ethanol or methanol from the whole plant, leaf and stem [9-11] include over 20 diterpenoids and over ten flavonoids have been reported from A. paniculata [12,13]. Andrographolide $\left(\mathrm{C}_{20} \mathrm{H}_{30} \mathrm{O}_{5}\right)$ is the major diterpenoid in A. paniculata, making up about $4 \%, 0.8 \sim 1.2 \%$ and $0.5 \sim 6 \%$ in dried whole plant, stem and leaf extracts respectively $[9,11,14]$. The other main diterpenoids are deoxyandrographolide, neoandrographolide, 14-deoxy-11,12-didehydroandrographide and isoandrographolide [9,15] (Table 1, Figure 1). From ethyl acetate $\left(\mathrm{EtOA}_{\mathrm{C}}\right)$-soluble fraction of the ethanol or methanol extract, 5-hydroxy-7,8-dimethoxyflavone, 5- 
Table 1: Bioactivities of compounds isolated from $A$. paniculata

\begin{tabular}{|c|c|c|}
\hline Names & Bioactivities & References \\
\hline Andrographolide & Bioactivities & \\
\hline 14-deoxyandrographolide & $\begin{array}{l}\text { activation of NOS and guanylate cyclase } \\
\text { vasorelaxation in vitro and in vivo }\end{array}$ & {$[102,103,106]$} \\
\hline neoandrographolide & $\begin{array}{l}\mathrm{NO}, \mathrm{PGE}_{2} \text {, iNOS and COX-2 in activated macrophages } \\
\mathrm{CCl}_{4}, \mathrm{tBHP} \text {-induced hepatotoxicity (i.p } 100 \mathrm{mg} / \mathrm{kg}, 3 \mathrm{~d} \text { ) }\end{array}$ & {$[34,35,91]$} \\
\hline 14-deoxy-11,12-didehydroandrographolide & $\begin{array}{l}\text { muscle relexation. } \\
\text { NO release from endothelial cells }\end{array}$ & {$[107,105]$} \\
\hline 14-deoxy-14,15-didehydroandrographolide & $\begin{array}{l}\text { cytotoxic activity and cell cycle arrest of tumor cells } \\
\text { NF-KB-dependent trans-activation }\end{array}$ & {$[42,17]$} \\
\hline andrograpanin & $\begin{array}{l}\text { protein kinase or p38 MAPKs pathways } \\
\text { chemokine SDF-1a induced chemotaxis in Jurkat and } \\
\text { THP-1 cells }\end{array}$ & {$[37,87]$} \\
\hline isoandrographolide & $\begin{array}{l}\text { cell-differentiation-inducing activity } \\
\text { proliferation of } \mathrm{HL}-60 \text { cells }\end{array}$ & {$[10,44]$} \\
\hline 14-acetylandrographolide & growth of leukeamia, ovarian, renal cancer cells & [47] \\
\hline 19-O-acetylanhydroandrographolide & NF-KB-dependent trans-activation & [17] \\
\hline
\end{tabular}

hydroxy-7,8,2',5'-tetramethoxyflavone, $7,8,2^{\prime}, 3^{\prime}$-tetramethoxyflavone,

5-hydroxy5-hydroxy-7,8,2'trimethoxyflavone, 7-O-methylwogonin and 2'-methyl ether were isolated as the main flavonoids [15-18] (Figure 2).

Andrographolide exhibits multiple pharmacological properties and is a potential chemotherapeutic agent [19]. Andrographolide contains an $\alpha$-alkylidene $\gamma$-butyrolactone moiety and three hydroxyls at C-3, C-19 and C-14 responsible for the cytotoxic activities of andrographolide against many cancer cell lines [19]. Andrographolide is abundant in leaves and can be easily isolated from the crude plant extracts as crystalline solid $[5,10,17,20,21]$.

\section{Pharmacological properties}

A. paniculata exhibits a vast range of pharmacological properties (Tables 2 and 3 ).

\section{Anti-inflammation effects}

Systemic inflammation was suggested to be associated with increased risk of chronic diseases such as cardiovascular disease, cancer and insulin resistance [22]. Inflammation involves macrophage and $\mathrm{T}$ lymphocyte activation as well as the release of pro-inflammatory mediators, such as tumour necrosis factor (TNF)- $\alpha$, interleukin (IL)-1, IL-6, interferon (IFN)- $\gamma$, nitric oxide (NO) and cell adhesion molecules which in turn amplify the inflammation [23]. Effective modulation of the aberrant production of these molecules may reduce inflammation $[24,25]$.

A previous study demonstrated that intraperitoneal (i.p.) administration of $A$. paniculata methanol extract for five consecutive days (50 mg/day) inhibited 65\% NO production by peritoneal macrophage and significantly inhibited carageenan induced paw oedema formation in mice [26]. Andrographolide inhibits nitric oxide (NO) production and the expression and stability of inducible synthase (iNOS) protein in lipopolysaccharide (LPS)stimulated RAW264.7 (RAW) cells [27,28]. Andrographolide inhibits oxygen radical production in neutrophils [29], inhibits macrophage migration [30], NF- $\mathrm{kB}$ activity $[31,32]$ as well as TNF- $\alpha$ and IL-12 production [33]. These anti-inflammatory activities of andrographolide may be a result of its interference with protein kinase Cdependent pathway, extracellular signal-regulated kinase1/2 (ERK1/2) or PI3K/Akt signalling pathway.

Neoandrographolide, isolated from EtOAc portion in methanol extract, suppresses NO production both in vitro and ex vivo in bacillus Calmette-Guéin (BCG)induced peritoneal macrophages [34] in mice. Neoandrographolide inhibits in vitro $\mathrm{TNF} \alpha$ and $\mathrm{PGE}_{2}$ production in RAW cells, suppresses ear oedema induced by dimethyl benzene in mice [35,36]. Andrograpanin, a hydrolysate from neoandrographolide, reduces NO, TNF $\alpha$ and IL- 6 production in LPS-activated macrophage cells derived from bone marrow in mice, possibly due to down-regulation of p38 mitogen-activated protein kinase (MAPKs) signalling pathways [37].

To screen for anti-inflammatory herbs, we transfected luciferase (with NF-kB binding site) into murine macrophage RAW cells and measured the suppression of luciferase activities [38]. EtOAc extract of A. paniculata inhibited NF-kB-dependent luciferase gene expression and suppressed TNF- $\alpha$, IL-6, macrophage inflammatory protein-2 (MIP-2), NO and $\mathrm{PGE}_{2}$ production by LPS/ IFN $\gamma$-stimulated RAW cells $[5,39]$. In an endotoxin shock 


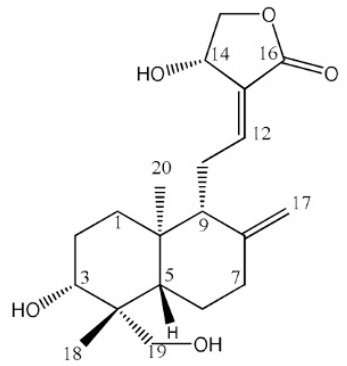

andrographolide<smiles>C=C1CC[C@]2(CO)[C@@](C)(CC[C@@H](O)[C@@]2(C)CO)[C@@H]1/C=C/C1=CCOC1=O</smiles>

14-deoxy-11,12-didehydroandrographolide

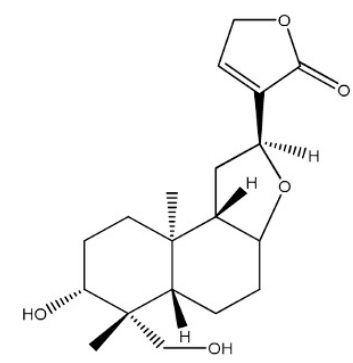

isoandrographolide<smiles>C=C1CCC2[C@](C)(CO)[C@@H](O)CC[C@]2(C)[C@H]1CCC1=CCOC1=O</smiles>

14-deoxyandrographolide<smiles>C=C1CC[C@]2(CO)[C@@](C)(CC[C@@H](C)[C@@]2(C)CO)[C@@H]1CC=C1C=COC1=O</smiles>

14-deoxy-14,15-didehydroandrographolide<smiles>C=C1CC[C@]2(C)[C@@](C)(CO)C(O)CC[C@]2(C)[C@H]1CC=C1C(=O)OCC1C(=O)O</smiles>

14-acetylandrographolide<smiles>C=C1CCC2[C@](C)(CO)CCC[C@]2(C)[C@H]1CCC1=CCOC1=O</smiles>

neoandrographolide<smiles>C=C1CCC2[C@](C)(CO)CCC[C@]2(C)[C@H]1CCC1=CCOC1=O</smiles>

andrograpanin<smiles>C=C1CC[C@]2(CO)[C@@](C)(CO)[C@@H](C)CC[C@]2(C)[C@H]1CC=C1C=COC1=O</smiles>

19-O-acetylanhydroandrographolide

Figure 1 Structures and bioactivities of compounds isolated from A. paniculata

model, the mice oral supplemented with AP EtOAc extract had significantly lower TNF- $\alpha$, MIP-2, IL-12 or $\mathrm{NO}$ in serum or peritoneal macrophages when challenged with LPS. Those LPS-challenged mice also had lower infiltration of inflammatory cells into the lung and higher survival rate [39].

Using bioactivity-guided chromatographic separation, we isolated the anti-inflammatory compounds from the EtOAc extract of $A$. paniculata and identified eight compounds with anti-inflammatory properties [17], namely andrographolide, 14-deoxy-11,12-didehydroandrographolide, ergosterol peroxide, 14-deoxy-14,15-dehydroan- drographolide, 5-hydroxy-7,8-dimethoxyflavone, 19-Oacetyl-14-deoxy-11,12-didehydroandrographolide, $\beta$ sitosterol, stigmasterol and 5-hydroxy-7,8-dimethoxyflavanone (Figure 3). The $\mathrm{IC}_{50}$ values of each compound for the inhibition of the pro-inflammatory cytokines were similar to those for NF-kB transcriptional activation (Table 4). Acetylation of andrographolide yields two compounds, namely 3,19-O-diacetylanhydroandrographolide and 19-O-acetylanhydroandrographolide. Other studies demonstrated that synthetic andrographolide derivatives such as 12-hydroxy-14-dehydroandrographolide derivatives and isopropylideneandrographolide had more 
<smiles>COc1cc(O)c2c(=O)cc(-c3ccccc3)oc2c1OC</smiles>

5-hydroxy-7,8-dimethoxyflavone<smiles>COc1ccc(OC)c(-c2cc(=O)c3c(O)cc(OC)c(OC)c3o2)c1</smiles>

5-hydroxy-7,8,2',5'-tetramethoxyflavone<smiles>COc1cc(O)c2c(c1OC)OC(c1ccccc1)CC2=O</smiles>

5-hydroxy-7,8-dimethoxyflavanone<smiles>COc1cccc(-c2cc(=O)c3c(O)cc(OC)c(OC)c3o2)c1OC</smiles>

5-hydroxy-7,8,2',3'-tetramethoxyflavone

Figure 2 Structures and bioactivities of flavonoids isolated from A. paniculata.

inhibitory activities than andrographolide [13,40] (Table 5, Figure 4). Therefore, the NF- $\mathrm{kB}$ dependent luciferase reporter assay may help screen anti-inflammatory Chinese medicinal herbs and isolate their bioactive compounds [5].

\section{Anti-cancer effects}

Kumar et al. fractionated the methanol extract of $A$. paniculata into dichloromethane, petroleum ether and aqueous extracts and found that only the dichloromethane fraction significantly inhibited the proliferation of HT-29 colon cancer cells [41]. They further fractionated the dichloromethane extract and yielded three diterpene compounds, namely andrographolide, 14-deoxyandrographolide and 14-deoxy-11,12-didehydroandrographolide. Andrographolide showed the greatest anti-cancer activity on a range of cancer cells [41]. The A. paniculata ethanol extract showed cytotoxic activities against human cancer cell lines, such as Jurkat (lymphocytic), PC-3 (prostate), HepG2 (hepatoma) and Colon 205 (colonic) cells [42]. An in vivo study demonstrated that $A$. paniculata $70 \%$ ethanol extract and andrographlide increased the life spans of mice injected with thymoma cells [43]. Isolated from $85 \%$ ethanol extract of A. paniculata, andrographolide and isoandrographolide exhibited higher antiproliferative activities in human leukaemia HL-60 cells than other 16 ent-labdane diterpenoids with $\mathrm{IC}_{50}$ 's of 9.33 and $6.30 \mu \mathrm{M}$ respectively [44].

The anti-cancer mechanisms of andrographolide have been investigated [19]. Andrographolide and its analogues exert direct anti-cancer activities on cancer cells by cell-cycle arrest at G0/G1 phase through induction of cell-cycle inhibitory protein and decreased expression of cyclin-dependent kinase [45-49]. Other compounds may block the cell cycle progression at G2/M phase [42]. Andrographolide inhibits human hepatoma cell growth through activating c-Jun N-terminal kinase [50] or inducing cell differentiation [51]. Andrographolide induces apoptosis in human cancer cells via the activation of caspase 8 , pro-apoptotic Bcl-2 family members Bax conformational change, release of cytochrome $\mathrm{C}$ from 
Table 2: Pharmacological properties of various extracts of A. paniculata

\begin{tabular}{|c|c|c|}
\hline Chemicals & Pharmacological properties & References \\
\hline methanol extract & $\begin{array}{l}\text { restore plasma lipid peroxidation, ALT, AST activities in } \mathrm{CCl}_{4} \text {-treated rats (orally } 1 \mathrm{~g} / \mathrm{kg} \\
\mathrm{BW}, 14 \mathrm{~d} \text { ) }\end{array}$ & [94] \\
\hline \multirow[t]{5}{*}{ ethanol extract } & $\begin{array}{l}\text { serum anti-Salmonella typhinurium IgG levels } \\
\text { IFN- } \gamma \text { in Con A-stimulated splenocytes of mice (orally, } 25 \text { or } 50 \mathrm{mg} / \mathrm{kg} \mathrm{BW}, 14 \mathrm{~d} \text { ) }\end{array}$ & {$[76]$} \\
\hline & antibody and the delayed-type hypersensitivity response (orally $25 \mathrm{mg} / \mathrm{kg}, 7 \mathrm{~d}$ ) & [74] \\
\hline & $\begin{array}{l}\text { G0/G1 phase } \\
\text { mitochondrial CYP and expression of Bax in human leukemic HL-60 cells }\end{array}$ & [49] \\
\hline & expression of EBV lytic proteins during the viral lytic cycle in P3HR1 cells & {$[82]$} \\
\hline & $\begin{array}{l}\text { fasting serum glucose in diabetic rats (orally } 0.1,0.2 \text {, and } 0.4 \mathrm{~g} / \mathrm{BW}, 14 \mathrm{~d} \text { ) } \\
\text { liver and kidney TBARS levels } \\
\text { liver GSH concentrations (orally } 400 \mathrm{mg} / \mathrm{kg} \mathrm{BW}, 14 \mathrm{~d} \text { ) }\end{array}$ & [113] \\
\hline $95 \%$ ethanol extract & $\begin{array}{l}\text { RANTES secretion by human bronchial epithelial cells infected with influenza A virus } \\
\text { H1N1 }\end{array}$ & {$[86]$} \\
\hline $80 \%$ ethanol extract & hepatic GPX, GR, CAT, SOD; lipid peroxidation (orally 50, 100 mg/kg BW, 14d) & [121] \\
\hline \multirow[t]{2}{*}{$70 \%$ ethanol extract } & CTL production through enhanced secretion of IL- 2 and IFN $\gamma$ by EL- 4 T cells & [43] \\
\hline & $\begin{array}{l}\text { serum NO, VEGF and TIMP-1, angiogenesis in melanoma cell implanted mice (i.p. } 10 \\
\mathrm{mg} / \mathrm{d}, 5 \mathrm{~d})\end{array}$ & [56] \\
\hline $95 \%$ ethanol or EtOAc extract & pi class of glutathione S-transferase expression in rat primary hepatocytes & [99] \\
\hline EtOAc extract & $\begin{array}{l}\text { NF-KB trans-activation assayed by NF-KB-dependent luciferase activity } \\
\text { ex-vivo } \mathrm{NO} \text { and } \mathrm{PGE}_{2} \text { production by } \mathrm{LPS} / \mathrm{IFN}-\gamma \text {-stimulated peritoneal macrophages } \\
\text { LPS-induced acute inflammation in mice (orally } 0.78 \sim 3.12 \mathrm{mg} / \mathrm{kg} \mathrm{BW}, 7 \mathrm{~d} \text { ) }\end{array}$ & {$[5,39]$} \\
\hline \multirow[t]{4}{*}{ aqueous extract } & $\begin{array}{l}\text { protect nicotine-induced toxicity in brain (i.p. } 250 \mathrm{mg} / \mathrm{kg} \mathrm{BW}, 7 \mathrm{~d} \text { ) } \\
\text { nicotine induced DNA fragmentation in lymphocytes, lipid peroxidation, protein } \\
\text { oxidation }\end{array}$ & {$[93,92]$} \\
\hline & systolic blood pressure of SHR and WKY rats (i.p. 0.7, 1.4, 2.8 g/kg BW) & [101] \\
\hline & blood glucose in STZ-induced hyperglycaemic rats (50 mg/kg BW, 10d) & [115] \\
\hline & hepatic CAT, SOD and GST activities in lymphoma bearing mice (orally $10 \sim 30 \mathrm{mg} / \mathrm{d}$ ) & [123] \\
\hline
\end{tabular}

mitochondria and activation of caspase cascade [52] and/ or via the activation of tumour suppressor p53 by ROSdependent c-Jun $\mathrm{NH}_{2}$-terminal kinase (JNK) activation, thereby increasing $\mathrm{p} 53$ phosphorylation and protein stabilization [53,54]. Andrographolide may suppress an oncogene v-Src-induced transformation and down-regulate v-Src protein expression via the attenuation of ERK1/ 2 signalling pathway [55].

In addition, enhancement of immunity and inhibition of angiogenesis and tumour cell migration may also contribute to the anti-cancer effects. Inhibiting human cancer cell growth, A. paniculata extract enhances proliferation and IL-2 induction in human peripheral blood lymphocytes [41]. Sheeja et al. showed that the $A$. paniculata ethanol extract and andrographolide stimulated the cytotoxic $\mathrm{T}$ lymphocytes (CTL) activity through enhanced release of IL-2 and IFN $\gamma$ in serum thereby inhibiting tumour growth [43]. The A.paniculata ethanol extract and andrographolide successfully inhibited the tumour specific capillary sprouting without damaging the pre-existing vasculature in mice injected with melanoma cells. A. paniculata extract inhibits tumour specific angiogenesis by down-regulating various proangiogenic molecules such as vascular endothelial growth factor (VEGF), NO and proinflammatory cytokines and up-regulating anti-angiogenic molecules such as IL-2 and tissue inhibitors of metalloproteinase-1 (TIMP-1) which prevent tumour metastasis [56]. As tumour cells can express high levels of sialyl Lewis surface antigens that interact with adhesion molecules E- and P-selectins on activated endothelial cells, cancer cell adhesion to endothelial cells followed by tumour extravasation results in metastasis. Andrographolide inhibits the adhesion of cancer cells to the activated endothelium by blocking E-selectin expression [57]. Andrographolide may also inhibit angiogenesis for tumour metastasis via down-regulating matrix metal- 
loproteinases-7 (MMP-7) expression, possibly by inactivating activator protein-1 (AP-1) through suppressing PI3K/Akt signalling pathway [58,59].

A novel semi-synthetic analogue of andrographolide, DRF3188, shows anti-cancer activities at a lower dosage than andrographolide through a similar mechanism [46]. Synthesis and structure-activity relationships of andrographolide analogues as novel cytotoxic agents reveals that intact $\alpha$-alkylidene $\gamma$-butyrolactone moiety of andrographolide, the D12(13) double bond, the C-14 hydroxyl or its ester moiety and the D8(17) double bond or epoxy moiety are responsible for the cytotoxic activities exhibited by andrographolide and its analogues [60]. Anti-cancer agents usually possess selective growth inhibition or cytotoxic properties [61]. The semi-synthesized andrographolide derivatives were screened against a panel of 60 human cancer cell lines. The results showed that 3,19-isopropylideneandrographolide was selective towards leukaemia and colon cancer cells whereas 14acetylandrographolide was selective towards leukaemia, ovarian and renal cancer cells [47]. The benzylidene derivatives of andrographolide showed more potent anticancer activities than andrographolide [62]. The addition of andrographolide to 5-Fluorouracil induces synergistic apoptosis [54]. Moreover, andrographolide enhances the sensitivity of cancer cells to a chemotherapeutic drug, namely doxorubicin, mainly via suppressing JAK-STAT3 [63]. The results of these studies suggest a potential therapeutic strategy of combining andrographolide with chemotherapeutic agents to treat cancer.

\section{Immunomodulatory effects}

Immune responses such as proliferation of lymphocytes, antibody production and cytokines secretion are regulated under normal conditions. Every immunocompetent cell is controlled by other cells with antagonistic action [64]. The balance between type $1 \mathrm{~T}$ helper cell-mediated and type 2 Th cell-mediated immune responses is critical for immunoregulation.

A. paniculata dichloromethane extract significantly augments the proliferation of human peripheral blood lymphocytes (hPBL) at low concentrations [41]. The three diterpene compounds including andrographolide enhance proliferation and IL-2 secretion in hPBL [41]. Andrographolide enhances secretion of IL-2 and IFN $\gamma$ by $\mathrm{T}$ cells and stimulates the production of cytotoxic $\mathrm{T}$ lymphocytes [43,65].

On the other hand, when murine $\mathrm{T}$ cell is stimulated with mitogen, IL-2 was decreased by andrographolide [66] possibly via reducing nuclear factor of activated $\mathrm{T}$ cells (NFAT) activities and increasing JNK phosphorylation [67]. Similarly, andrographolide interferes with $\mathrm{T}$ cell activation and reduces the severity of experimental autoimmune encephalomyelitis (EAE) in mice. Clinical signs of disease such as abnormal gait and limb paralysis, pro- liferation and IL-2 secretion of lymph node cells, as well as cell-dependent antibody production in EAE mice were reduced by andrographolide treatment [68]. Andrographolide is beneficial for inflammation-related immune dysregulatory diseases, such as allergic asthma, rheumatoid (RA) and neurodegenerative diseases via inhibition of the NF-kB signalling pathway [69]. Andrographolide reduces inflammation-mediated dopaminergic neurodegeneration in mesencephalic neuron-glial cultures by inhibiting microglial activation and production of proinflammatory factors such as TNF $\alpha, \mathrm{NO}$ and $\mathrm{PGE}_{2}$ [70]. Andrographolide inhibits OVA-induced increases in total cells, eosinophils and IL-4, IL-5 and IL-13 levels in bronchoalveolar lavage fluid (BALF), and reduces serum level of OVA-specific IgE [71]. Andrographolide attenuated OVA-induced lung tissue eosinophils and airway mucus production, mRNA expression of E-selectin, chitinases, mucin Muc5ac and iNOS in lung tissues and airway hyperresponsiveness [71]. Andrographolide inhibits OVA-induced increases TNF- $\alpha$ and GM-CSF in BALF of OVA-sensitized and nasally-challenged mice [72]. A recent clinical study showed that $A$. paniculata extract (30\% andrographolide) reduced the symptoms and certain immunological parameters such as serum immunoglobulins and complement components in patients with rheumatoid arthritis during a 14-week treatment [73].

Oral administration of the $A$. paniculata ethanol extract or andrographolide to mice stimulated antibody production and the delayed-type hypersensitivity response to sheep red blood cells [74]. Andrographolide increases spontaneous IFN $\gamma$ and mitogen-stimulated TNF- $\alpha$ secretion by cultivated human peripheral blood cells [75]. Oral pre-treatment of the A. paniculata ethanol extract or andrographolide in mice immunized with an inactivated Salmonella typhimurium vaccine enhances Salmonella-specific IgG antibody and IFN- $\gamma$ production [76]. Recent study demonstrated that the cyclophosphamide-potentiated DTH reaction was reversed by a pure powder mixture of andrographolide plus 14-deoxyandrographolide and 14-deoxy-11,12-didehydroandrographolide together. The mixture stimulated phagocytosis, and elevated antibody titer and plaque-forming cells in the spleen cells in mice [77].

\section{Anti-infective effects}

The aqueous extract of $A$. paniculata against anti-human immunodeficiency virus (HIV) was ruled out by testing the inhibitory activities against HIV in the H9 cell line [78]. Reddy et al. tested the anti-HIV activity of the nhexane and methanol extracts of $A$. paniculata. Seven compounds, namely andrographolide, bis-andrographolide 14-deoxy-11,12-didehydroandrographolide, andrograpanin, 14-deoxyandrographolide, $( \pm)-5$ hydroxy-7,8-dimethoxyflavanone and 5-hydroxy-7,8dimethoxyflavone. Andrographolide and 14-deoxy- 
Table 3: Pharmacological properties of andrographolide

Pharmacological properties
Anti-inflammation
LPS-induced NO production by suppressing iNOS
complement 5 a-induced macrophage recruitment
via ERK $1 / 2$ and $\mathrm{PI} 3 \mathrm{~K}$ signal pathways
binding of NF-KB oligonucleotide to nuclear
proteins via ERK1/2 or PI3/AKt signal pathway

\section{References}

[28,31-33]

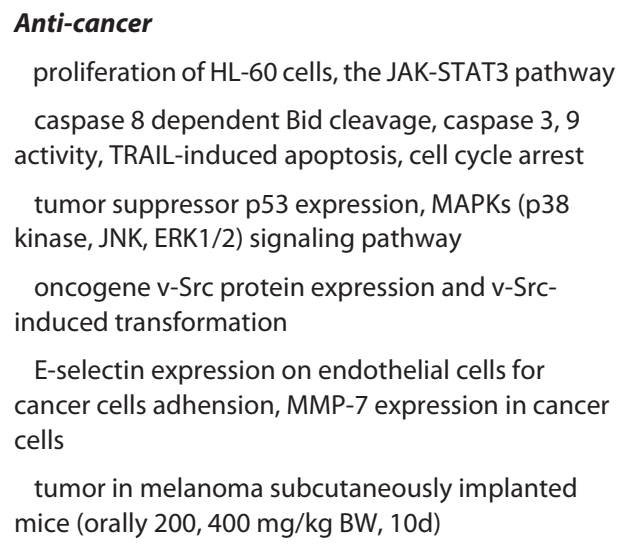

\section{Immunomodulation}

proliferation and IL-2 induction in hPBL

antibody and the delayed-type hypersensitivity response (orally $1 \mathrm{mg} / \mathrm{kg}, 7 \mathrm{~d}$ )

serum anti-Salmonella lgG, IFN- $\gamma$ in activated splenocytes of mice (orally 1, $4 \mathrm{mg} / \mathrm{kg} \mathrm{BW}, 14 \mathrm{~d}$ )

TNF- $a$ and GM-CSF in BALF of OVA-sensitized and nasally-challenged mice (i.p. $3 \sim 30 \mathrm{mg} / \mathrm{kg} \mathrm{BW}$ )

IL-4, IL-5 and IL-13 in BALF and OVA-specific IgE in

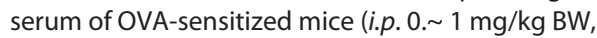
twice)

NF-KB expression in lung and airway epithelial cells [69] infiltration of inflammatory cells in lung, airway hyperreactivity (i.p. $2 \mu \mathrm{g} / \mathrm{g} \mathrm{BW}, 7 \mathrm{~d}$ )

expression of IL-2 via NFAT and JNK phosphorylation in murine T-cells

LPS induced dopaminergic neurodegeneration in primary rat mesencephalic neuron-glial cultures

IL-2 production, proliferation, antibody production, T cell activation in EAE (i.p. $4 \mathrm{mg} / \mathrm{kg} \mathrm{BW}$ )

symptom and immunological markers in patients with RA ( $30 \%$ andrographolide tablet, 14 weeks)

\section{Anti-infection}

HIV induced cell cycle dysregulation, CD4 ${ }^{+}$ lymphocyte levels in HIV-1 infected individuals

$[48,52,53,63]$

$[50,54]$
Table 3: Pharmacological properties of andrographolide

viricidal activity against HSV-1, EBV, via producing [81,82]
mature virus particle

\section{Anti-hepatotoxicity}

CYP1A1 and CYP1A2 mRNA in mouse hepatocytes, [95,96] synergistic effect in with a CYP1A1 inducer

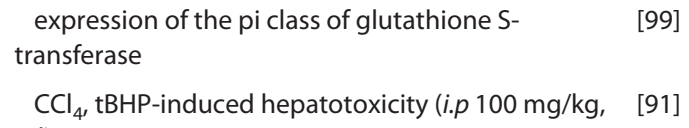

\section{Anti-atherosclerosis}

HUVECs apoptosis via enhancement of PI3K-Akt [108] activity

thrombin-induced platelet aggregation via ERK1/ [109]

2 pathway

\section{Anti-hyperglycemic effect}

plasma glucose concentrations of STZ-diabetic rats $[117,118]$ (oral $1.5 \mathrm{mg} / \mathrm{Kg}$ )

mRNA and protein levels of GLUT4 in soleus muscle

\section{Anti-Oxidation}

MDA formation

[91]

GSH, SOD activity

$[92,93]$

11,12-didehydroandrographolide showed anti-HIV activity with $50 \%$ effective concentration $\left(\mathrm{EC}_{50}\right)$ of 49 and 57 $\mu \mathrm{g} / \mathrm{ml}$ respectively [79]. A phase I dose-escalating clinical trial of andrographolide in HIV positive patients reported a significant rise in the mean $\mathrm{CD}^{+}$lymphocyte level of HIV patients. Andrographolide inhibits HIV-induced cell cycle dysregulation, leading to a rise in $\mathrm{CD} 4^{+}$lymphocyte levels in HIV-1 infected individuals [80].

Andrographolide, neoandrographolide and 14-deoxy11,12-didehydroandrographolide isolated from $A$. paniculata demonstrated viricidal activity against herpes simplex virus 1 (HSV-1) without significant cytotoxicity [81]. The A. paniculata ethanol extract and andrographolide inhibit the expression of Epstein-Barr virus (EBV) lytic proteins during the viral lytic cycle in P3HR1 cells, an oral lymphoma cell line latently infected by EBV. Andrographolide inhibits the production of mature viral particles and is not toxic to P3HR1 cells [82].

A recent in vitro study investigated the anti-influenza activity of $A$. paniculata in canine kidney cell line as well as mice infected with $\mathrm{H} 1 \mathrm{~N} 1, \mathrm{H} 9 \mathrm{~N} 2$ or $\mathrm{H} 5 \mathrm{~N} 1$ [83]. A 
newly synthesized andrographolide derivative 14- $\alpha$-lipoyl andrographolide was more effective against avian influenza A (H9N2 and H5N1) and human influenza A H1N in vitro than andrographolide [83]. Another andrographolide analogue 14-glycinyl andrographolide hydrochloride inhibits virulence factor production and bacterial growth [84]. Moreover, a double blind, placebo-controlled, parallel-group clinical study on a combined formula of A. paniculata extract and Acanthopanax senticocus, also known as Kan Jang, demonstrated the formula's positive effects in treating acute upper respiratory tract infections and relieving the inflammatory symptoms of sinusitis [85].

The migratory response of leukocytes to chemokines forms the first line of defence to the invading microbial. A. paniculata extract inhibits secretion of RANTES, a potent chemoattractant exacerbating bronchial inflammation as a result of H1N1-infected human bronchial epithelial cells [86]. Andrograpanin enhanced chemokine stromal cell-derived factor- $1 \alpha$ (SDF- $1 \alpha$ ) induced chemotaxis in Jurkat and THP-1 cells via CXC chemokine receptor-4 specific induced cell chemotaxis [87]. Andrograpanin enhancing chemokine-induced leukocyte chemotaxis may contribute to the anti-infectious function of A. paniculata. Post-translational cleavage by proprotein convertase is one of the several events that determine the viral infectivity and virulence [88]. The inhibitory action of andrographolide was enhanced significantly by the formation of dehydroandrographolide succinic acid monoester (DASM) via succinoylation [88]. DASM inhibits HIV by interfering with HIV-induced cell fusion and with HIV's binding to the cell [89].

\section{Anti-hepatotoxic effects}

Liver metabolizes xenobiotics, such as drugs, toxins and chemical carcinogens; chronic liver injury leads to cirrhosis. Anti-hepatotoxic enzymes include cytochrome P450 (CYP) super-family, or normalizing the levels of marker enzymes for the liver function test, such as glutamate oxaloacetate transaminase (GOT), glutamate pyruvate transaminase (GPT), acid phosphatase (ACP) and alkaline phosphatase (ALP) [90].

An early study showed that pre-treatment of mice with andrographolide, andrographiside and neoandrographolide alleviated hepatotoxicity induced by intoxication of carbon tetrachloride $\left(\mathrm{CCl}_{4}\right)$ or tert-butylhydroperoxide (tBHP) in mice [91]. The glucoside groups in andrographolid and neoandrographolide were suggested to act as strong antioxidants. The A. paniculata aqueous extract and andrographolide decreased oxidative stress in isolated rat lymphocytes exposed to nicotine [92]. The $A$. paniculata aqueous extract and andrographolide ameliorated the dysfunction in the brain associated with nicotine toxicity [93]. Arabinogalactan, another aqueous component of the A. paniculata, Tris-buffer extract and andrographolide minimized the toxicity in pre-treated mice [90]. Oral treatment of rats with the A. paniculata methanol extract followed by $\mathrm{CCl}_{4}$ administration restored plasma lipid peroxidation, alanine transaminase (ALT) and aspartate transaminase (AST) [94].

Andrographolide significantly induced the expression of CYP1A1 and CYP1A2 mRNAs in a concentrationdependent manner, and synergistically induced CYP1A1 expression with the typical CYP1A inducers $[95,96]$. In addition, the A. paniculata $60 \%$ ethanol extract or andrographolide may cause herb-drug interactions through CYP3A and CYP2C9 inhibition in vitro or CYP2C11 inhibition in vivo [97,98]. Induction of drugmetabolizing enzymes is considered to be an adaptive response to a cytotoxic environment. The A. paniculata ethanol extract, EtOAc extract and andrographolide induce the expression of the pi class of glutathione Stransferase, a phase II biotransformation enzymes involved in detoxification of various classes of environmental carcinogens, in rat primary hepatocytes [99]. A recent study showed that this induction by andrographolide was suppressed by the increase of cAMP or cAMP analogues [100].

\section{Anti-atherosclerotic effects}

Zhang et al. reported that the A. paniculata aqueous extract lowers systolic blood pressure (SBP) of both spontaneously hypertensive rats (SHR) and the control Wistar-Kyoto rats [101]. The A. paniculata water, nbutanol and aqueous extracts produce a significant fall in mean arterial blood pressure (MAP) without significant decrease in heart rate in anaesthetized Sprague-Dawley rats [102]. The 14-deoxyandrographolide isolated from the $A$. paniculata methanol extract showed vasorelaxant effects in isolated rat thoracic aorta [103]. Another diterpenoid isolated from A. paniculata methanol extract, 14deoxy-11,12-didehydroandrographolide, significantly reduces MAP and heart rate and beating rate of isolated right atria in anaesthetised rats [104]. These two diterpenoids may exert their vasorelaxant activities through the activation of the NOS and guanylyl cyclase for NO release from endothelial cells [105]. Moreover, 14deoxyandrographolide reduces the contractile response by calcium channel-dependent rat uterine smooth muscle contraction [106] The vascular smooth muscle is the major site of the hypotensive effects of the A. paniculata hot water extract and 14-deoxy-11,12-didehydroandrographolide [107], suggesting relaxant effects of $A$. paniculata in muscle.

Andrographolide suppresess apoptosis of human umbilical vein endothelial cells (HUVECs) induced by growth factor deprivation via the activation of PI3/Akt pathway [108]. The aqueous extracts significantly decreased platelet aggregation in vitro [107]. Andrographolide and 14-deoxy-11,12-didehydroandrographolide 


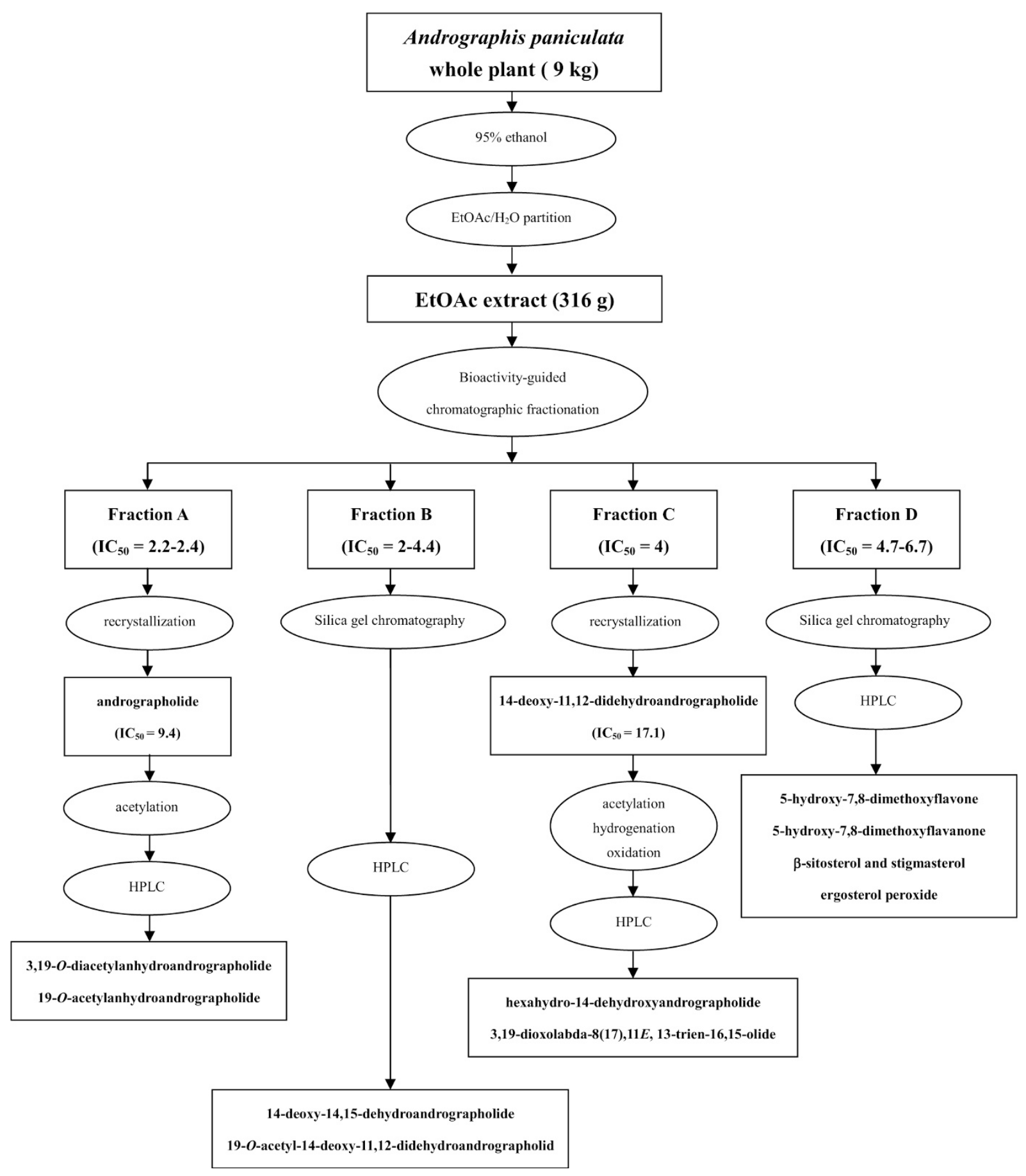

Figure 3 Extraction procedure for the isolation and identification $A$. paniculata pure compounds from EtOAc extract. Dried whole plant of $A$. paniculata is pre-extracted with $95 \%$ ethanol and then partitioned in $\mathrm{EtOAc} / \mathrm{H}_{2} \mathrm{O}$ for further fractionation. 


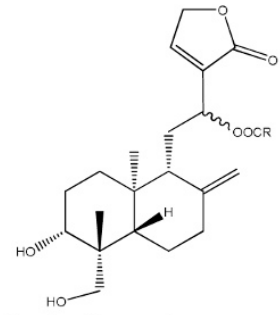

Derivatives of

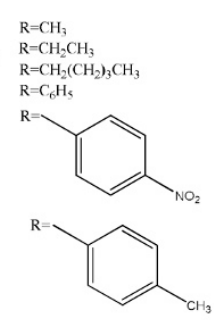

$\mathrm{R}=\mathrm{CH}_{2} \mathrm{CH}_{3}$ $\mathrm{R}=\mathrm{CH}_{2}(\mathrm{C}$
$\mathrm{R}=\mathrm{C}_{6} \mathrm{H}_{4}$

12-hydroxy-14-dehydroandrographolide<smiles>C=C1CCC2[C@@](C)(CC[C@@H](C)[C@@]2(C)CO)[C@@H]1CC=C1C(=O)OCC1OC(=O)CCCCC1CCSS1</smiles>

14-Alphal-lipoyl andrographolide<smiles>C=C1CCC2C3(C)COC(c4ccccc4F)OC3CC[C@@]2(C)[C@H]1CC=C1C(=O)OC[C@@H]1O</smiles>

SRJ09

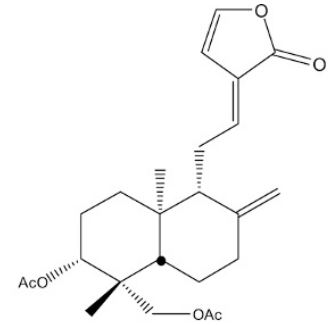

3,19-O-diacetylanhydroandrographolide<smiles>C=C1CCC2[C@@](C)(CC[C@@H](C)[C@@]2(C)CO)[C@H]1C/C=C1/C(=O)OCC1OC(=O)CN</smiles>

14-Glycinyl andrographolide hydrochloride<smiles>C=C1CCC2C3(C)COC(C)(C)OC3CC[C@@]2(C)[C@@H]1CC=C1C(=O)OCC1O</smiles>

3,19-isopropylideneandrographolide<smiles>C[C@]12CC[C@H](O)[C@@](C)(CO)C1CC[C@]1(CO1)[C@H]2C/C=C1/C(=O)OC[C@@H]1OC(=O)/C=C/c1ccccc1</smiles>

DRF3188<smiles>C=C1CCC2OC(c3ccc(F)c(Cl)c3)OCC2(C)[C@@H]1CC=C1C(=O)OCC1O</smiles>

SRJ23<smiles>C=C1CCC2C3(C)COC(C)(C)OC3CC[C@@]2(C)[C@@H]1CC=C1C(=O)OCC1OC</smiles>

14-acetyl-3,19-isopropylidene andrographolide

Figure 4 Structures and bioactivities of synthesized analogues.

significantly inhibited thrombin-induced platelet aggregation whereas neoandrographolide had little or no activity. The inhibition of ERK1/2 pathway may contribute to anti-platelet activity [109]. Four flavonoids, namely 7-Omethylwogonin, apigenin, onysilin and 3,4dicaffeoylquinic acid inhibit collagen, arachidonic acid, thrombin and platelet activation factor induced platelet aggregation; 14-deoxy-11,12-dihydroandrographolide demonstrated moderate vasorelaxing effects in isolated rat thoracic aorta [110].

\section{Anti-hyperglycaemic effects}

Hyperglycaemia is involved in the aetiology of development of diabetic complications. Hypoglycaemic herbs increase insulin secretion, enhance glucose uptake by adipose or muscle tissues and inhibit glucose absorption from intestine and glucose production from liver [111]. Oral administration of the A. paniculata ethanol extract significantly reduced the fasting serum glucose level in streptozotocin (STZ) induced diabetic rats. No significant change in insulin level was observed among the 
Table 4: The IC 50 values of NK-B transactivation and pro-inflammatory mediators of the compounds isolated or semisynthesized from $A$. paniculata EtOAc extract

\begin{tabular}{|c|c|c|c|c|c|}
\hline Compounds & NF-KB & TNFa & IL-6 & MIP-2 & NO \\
\hline Semi-synthetic analogues & & & $(\mu \mathrm{g} / \mathrm{ml})$ & & \\
\hline 3,19-O-diacetylanhydroandrographolide & 2.2 & 2.89 & 2.08 & 1.29 & 2.02 \\
\hline 19-O-acetylanhydroandrographolide & 2.4 & 3.85 & 2.75 & 2.29 & 2.08 \\
\hline \multicolumn{6}{|l|}{ Diterpenoids } \\
\hline 14-deoxy-14,15-dehydroandrographolide & 2.0 & 2.18 & 2.14 & 2.07 & 2.05 \\
\hline $\begin{array}{l}\text { 19-O-acetyl-14-deoxy-11,12- } \\
\text { didehydroandrographolide }\end{array}$ & 4.4 & 5.07 & 3.94 & 4.41 & 4.11 \\
\hline \multicolumn{6}{|l|}{ Synthetic analogues } \\
\hline hexahydro-14-dehydroxyandrographolide & 4.2 & 5.2 & 3.78 & 4.52 & 4.24 \\
\hline 3,19-dioxolabda-8(17),11E, 13-trien-16,15-olide & 4.1 & 5.78 & 3.97 & 4.67 & 4.52 \\
\hline \multicolumn{6}{|l|}{ Steroids } \\
\hline ergosterol peroxide & 4.7 & 4.71 & 5.32 & 4.55 & 4.67 \\
\hline$\beta$-sitosterol and stigmasterol & 5.2 & 5.34 & 5.97 & 4.88 & 4.55 \\
\hline \multicolumn{6}{|l|}{ Flavonoids } \\
\hline 5-hydroxy-7,8-dimethoxyflavone & 6.1 & 4.33 & 5.34 & 3.63 & 5.11 \\
\hline 5-hydroxy-7,8-dimethoxyflavanone & 6.7 & 4.37 & 5.14 & 4.01 & 4.57 \\
\hline \multicolumn{6}{|l|}{ Diterpenoids } \\
\hline andrographolide (major compound) & 9.4 & 5.62 & 8.93 & 5.48 & 8.48 \\
\hline 14-deoxy-11,12-didehydroandrographolide & 17.1 & 20.64 & 23.6 & 15.03 & 11.26 \\
\hline
\end{tabular}

NF-kB trans-activation activity was assay as following: RAW 264.7 macrophages transiently transfected with NF-KB reporter plasmids were pretreated various compounds and then stimulated with LPS $100 \mathrm{ng} / \mathrm{mL} / \mathrm{IFN}-\gamma 1000$ units $/ \mathrm{mL}$ for further was estimated by the Dual-Glo Luciferase reporter assay. The collected cell supernatants were assayed for TNFa, IL-6, and MIP-2 productions using commercial ELISA kits. NO was determined by Griess assay [17].

three groups of diabetic rats. The activity of hepatic glucose-6-phosphalase (G-6-Pase) and fasting serum triglyceride levels were significantly reduced by the $A$. paniculata extract [112]. In addition to its hypoglycaemic action, the $A$. paniculata may also reduce oxidative stress in diabetic rats [113]. An in vitro study and in vivo oral carbohydrate tolerance tests in STZ-induced diabetic rats suggest that $\alpha$-glucosidase inhibition may be responsible for the anti-diabetic activity of $A$. paniculata ethanol extract [114].

The $A$. paniculata aqueous extract significantly reduces blood glucose in hyperglycaemic rats without significantly changing the rats' weight [115]. However, alloxaninduced diabetic rats treated with $A$. paniculata water extract had higher body weight than the positive (diabetic) controls; the blood glucose levels were significantly reduced and impaired oestrous cycle in alloxan-induced diabetic rats was restored [116].

Andrographolide significantly attenuated the increase of plasma glucose induced by an intravenous glucose challenge test in normal rats. Andrographolide enhanced the uptake of glucose and the mRNA and protein levels of the glucose transporter subtype 4 (GLUT4) in soleus muscle in STZ-diabetic rats [117]. Andrographolide not only reduced expression of phosphoenolpyruvate carboxykinase (PEPCK) in liver of STZ-diabetic rats, activated $\alpha 1$-adrenoceptors to enhance the secretion of $\beta$ endorphin, thereby stimulating the opioid $\mu$-receptors to reduce hepatic gluconeogenesis and to enhance the glucose uptake in soleus muscle, leading to a decrease of plasma glucose in STZ-diabetic rats [118]. A recent study showed that andrographolide-lipoic acid conjugate (an andrographolide analogue) had both hypoglycaemic and beta cell protective effects [119].

\section{Anti-oxidative activities}

Antioxidant action is manifested by a decrease of malondialdehyde (MDA) formation via lipid peroxidation and an increase of hepatic antioxidative enzymes and antioxidants such as glutathione peroxidase (GPX), glutathione reductase (GR), catalase (CAT), superoxide dismutase (SOD) and glutathione $\mathrm{S}$ transferase (GST). Anti-oxidative activity of $A$. paniculata contributes to its antiinflammatory, anti-cancer, anti-hepatotoxic, anti-atherosclerotic and anti-diabetic activities [27,44,91,108,117]. 
Table 5: Bioactivities of synthetic analogues of andrographolide

\begin{tabular}{|c|c|c|}
\hline Name & Bioactivities & References \\
\hline Derivatives of 12-hydroxy-14-dehydroandrographolide & TNF- $\alpha$ and IL- 6 secretion in mouse macrophages & [13] \\
\hline 3,19-O-diacetylanhydroandrographolide & NF-KB-dependent trans-activation in the RAW264.7 cells & [17] \\
\hline DRF3188 & $\begin{array}{l}\text { block MCF-7 cell cycle at the G0/G1 phase } \\
\text { cell cycle inhibitor, p27 } \\
\text { the levels of CDK4 }\end{array}$ & [46] \\
\hline 14-Alphal-lipoyl andrographolide & $\begin{array}{l}\text { against } \mathrm{H} 9 \mathrm{~N} 2, \mathrm{H} 5 \mathrm{~N} 1 \text { and } \mathrm{H} 1 \mathrm{~N} 1 \text { viruses to reduced the } \\
\text { death rate, prolonged life and inhibited lung } \\
\text { consolidation and viral titers }\end{array}$ & [83] \\
\hline 14-Glycinyl andrographolide hydrochloride & reduced virulence factor production & [84] \\
\hline SRJ23 & G1 arrest and apoptosis in MCF-7 and HCT-116 & [62] \\
\hline SRJ09 & G1 arrest and apoptosis in MCF-7 and HCT-116 & [62] \\
\hline 3,19-isopropylideneandrographolide & cyotoxicity against MCF-7 and HCT-116 & [47] \\
\hline 14-acetyl-3,19-isopropylidene andrographolide & cyotoxicity against MCF-7 and HCT-116 & [47] \\
\hline
\end{tabular}

An in vitro scavenging of superoxide radical assay suggests that neoandrographolide from the A. paniculata hexane/EtOA ${ }_{C}$ extract is an effective in vivo scavenger for small radicals [120].

An in vivo study demonstrated that the A. paniculata $80 \%$ ethanol extract enhanced murine hepatic antioxidative enzymes and antioxidants such as GPX, GR, CAT and SOD but reduced lipid peroxidation [121]. The $A$. paniculata methanol extract significantly lowered MDA levels and raised the total antioxidant status in urine samples 24 hours after oral administration [122]. The $A$. paniculata methanol extract preserved CAT and SOD activities in erythrocytes after $\mathrm{CCl}_{4}$ administration [94]. Oral administration of the $A$. paniculata aqueous extract significantly enhanced CAT, SOD and GST activities in the liver of lymphoma bearing mice [123]. Moreover, the A. paniculata aqueous extract exhibited more antioxidant action than its ethanol extract in terms of free radical scavenging, xanthine oxidase inhibition and anti-lipid peroxidation [124].

\section{Conclusion}

Among the single compounds extracted from $A$. paniculata, andrographolide is the major one in terms of bioactive properties and abundance. Among the andrographolide analogues, 14-deoxy-11,12-didehydroandrographolide is immunostimulatory, anti-infective and anti-atherosclerotic; neoandrographolide is antiinflammatory, anti-infective and anti-hepatotoxic; 14deoxyandrographolide is immunomodulatory and antiatherosclerotic. Among the less abundant compounds from $A$. paniculata, andrograpanin is both anti-inflammatory and anti-infective; 14-deoxy-14,15-dehydroandrographolide is anti-inflammatory; isoandrographolide, 3,19-isopropylideneandrographolide and 14-acetylandrographolide are tumor suppressive; arabinogalactan proteins are anti-hepatotoxic. The four flavonoids from A. paniculata, namely 7-O-methylwogonin, apigenin, onysilin and 3,4-dicaffeoylquinic acid are anti-atherosclerotic.

\section{Abbreviations}

TNF-a: tumour necrosis factor-a; IL-1: interleukin-1; IFN- $\gamma$ : interferon- $\gamma$; NO: nitric oxide; ERK1/2: extracellular signal-regulated kinase1/2; MAPK: mitogenactivated protein kinase; JNK: c-Jun $\mathrm{NH}_{2}$-terminal kinase; VEGF: vascular endothelial growth factor; TIMP-1: tissue inhibitors of metalloproteinase-1; MMP-7: matrix metalloproteinases-7; hPBL: human peripheral blood lymphocytes; NFAT: nuclear factor of activated T cells; EAE: experimental autoimmune encephalomyelitis; BALF: bronchoalveolar lavage fluid; HIV: human immunodeficiency virus; HSV-1: herpes simplex virus 1; EBV: Epstein-Barr virus; SDF-1a: stromal cell-derived factor-1a; CYP: cytochrome P450; CCl 4 : carbon tetrachloride; tBHP: rert-butylhydroperoxide; ALT: alanine transaminase; AST: aspartate transaminase; SBP: systolic blood pressure; SHR: spontaneously hypertensive rats; HUVECs: human umbilical vein endothelial cells; STZ: streptozotocin; GLUT4: glucose transporter subtype 4; MDA: malondialdehyde; GPX: glutathione peroxidise; GR: glutathione reductase; CAT: catalase; SOD: superoxide dismutase; GST: glutathione S transferase

\section{Competing interests}

The authors declare that they have no competing interests.

\section{Authors' contributions}

BFL and WWC searched the literature and drafted the manuscript. All authors read and approved the final version of the manuscript.

\section{Acknowledgements}

Part of this work was supported by a grant from the Committee on Chinese Medicine and Pharmacy of Department of Health, Taiwan (CCMP93-RD-052, CCMP94-RD-026, CCMP95-RD-105, CCMP95-RD-213, CCMP96-RD-214).

\section{Author Details}

Department of Biochemical Science and Technology, College of Life Science, National Taiwan University, Taipei 10617, Taiwan

Received: 4 March 2010 Accepted: 13 May 2010

Published: 13 May 2010 


\section{References}

1. Negi AS, Kumar JK, Luqman S, Sbanker K, Gupta MM, Kbanuja SPS: Recent advances in plant hepatoprotectives: a chemical and biological profile of some important leads. Med Res Rev 2008, 28(5):821.

2. Roxas M, Jurenka J: Colds and influenza: A review of diagnosis and conventional, botanical and nutritional considerations. Altern Med Rev 2007, 12:25-48.

3. Kligler B, Ulbricht C, Basch E, Kirkwood CD, Abrams TR, Miranda M, Singh Khalsa KP, Giles M, Boon H, Woods J: Andrographis paniculata for the treatment of upper respiratory infection: a systematic review by the natural standard research collaboration. Explore 2006, 2(1):25-29.

4. Huang CJ, Wu MC: Differential effects of foods traditionally regarded as 'heating' and 'cooling' on prostaglandin $\mathrm{E}_{2}$ production by a macrophage cell line. J Biomed Sci 2002, 9:596-606.

5. Chao WW, Kuo YH, Li WC, Lin BF: The production of nitric oxide and prostaglandin $\mathrm{E}_{2}$ in peritoneal macrophages is inhibited by Andrographis paniculata, Angelica sinensis and Morus alba ethyl acetate fractions. J Ethnopharmacol 2009, 122:68-75.

6. Mandal SC, Dhara AK, Maiti BC: Studies on Psychopharmacological Activity of Andrographis paniculata Extract. Phytother Res 2001, 15:253-256.

7. Rao YK, Vimalamma G, Rao CV, Tzeng Y: Flavonoids and andrographolides from Andrographis paniculata. Phytochemistry 2004 65:2317-2321.

8. Xu C, Chou GX, Wang ZT: A new diterpene from the leaves of Andrographis paniculata Nees. Fitoterapia 2010.

9. Cheung HY, Cheung CS, Kong CK: Determination of bioactive diterpenoids from Andrographis paniculata by micellar electrokinetic chromatography. J Chromatogr A 2001, 930(1-2):171-176.

10. Matsuda T, Kuroyanagi M, Sugiyama S, Umehara K, Ueno A, Nishi K: Cell differentiation inducing diterpenes from Andrographis paniculata Nees. Chem Pharm Bull (Tokyo) 1994, 42:1216-1225.

11. Pholphana N, Rangkadilok N, Thongnest S, Ruchirawat S, Ruchirawat M, Satayavivad J: Determination and variation of three active diterpenoids in Andrographis paniculata (Burm.f.) Nees. Phytochem Anal 2004, 15(6):365-371.

12. Kishore PH, Reddy MV, Reddy MK, Gunasekar D, Caux C, Bodo B. Flavonoids from Andrographis lineata. Phytochemistry 2003, 63(4):457-461

13. Li J, Huang W, Zhang H, Wang X, Zhou H: Synthesis of andrographolide derivatives and their TNF-alpha and IL-6 expression inhibitory activities. Bioorg Med Chem Lett 2007, 17(24):6891-6894.

14. Burgos RA, Caballero EE, Sánchez NS, Schroeder RA, Wikman GK, Hancke $J \mathrm{~L}$ : Testicular toxicity assessment of Andrographis paniculata dried extract in rats. J Ethnopharmacol 1997, 58(3):219-224.

15. Reddy MVB, Kishore PH, Rao CV, Gunasekar D, Caux C, Bodo B: New 2'oxygenated flavonoids from Andrographis affinis. J Nat Prod 2003, 66:295-297.

16. Kuroyanagi M, Sato M, Ueno A, Nishi K: Flavonoids from Andrographis paniculata. Chem Pharm Bull (Tokyo) 1987, 35(11):4429-4435.

17. Chao WW, Kuo YH, Lin BF: Anti-inflammatory Activity of New Compounds from Andrographis paniculata by NF-KB Trans-Activation inhibition. J Agric Food Chem 2010, 58:2505-2512.

18. Radhika P, Prasad YR, Lakshmi KR: Flavones from the stem of Andrographis paniculata Nees. Nat Prod Commun 2010, 5(1):59-60.

19. Varma A, Padh H, Shrivastava N: Andrographolide: A New Plant-Derived Antineoplastic Entity on Horizon. Evid Based Complement Alternat Med 2009 in press.

20. Patra A, Mitra AK: Carbon-13 NMR spectra of some labdane diterpenoids. Org Magn Reson 1981, 17(4):301-302.

21. Fujita T, Fujita R, Takeda Y, Takaishi Y, Yamada T, Kido M, Miura I: On the diterpenoids of Andrographis paniculata: X-ray crystallographic analysis of andrographolide and structure determination of new minor diterpenoids. Chem Pharm Bull (Tokyo) 1984, 32(6):2117-2125.

22. Davi G, Falco A: Oxidant stress, inflammation and atherogenesis. Lupus 2005, 14:760-764.

23. O'Shea JJ, Murray PJ: Cytokine signaling modules in inflammatory responses. Immunity 2008, 28(4):477-87.

24. O'keefe JH, Gheewala NM, O'keefe JO: Dietary strategies for improving post-prandial glucose, lipids, inflammation and cardiovascular health J Am Coll Cardiol 2008, 51:249-255.
25. Hong YH, Chao WW, Chen ML, Lin BF: Ethyl acetate extracts of alfalfa (Medicago sativa $L$.) sprouts inhibit lipopolysaccharide induced inflammation in vitro and in vivo. J Biomed Sci 2009, 16:64-75.

26. Sheeja K, Shihab PK, Kuttan G: Antioxidant and anti-inflammatory activities of the plant Andrographis paniculata Nees. Immunopharmacol Immunotoxicol 2006, 28(1):129-140

27. Chiou WF, Lin JJ, Chen CF: Andrographolide suppresses the expression of inducible nitric oxide synthase in macrophage and restores the vasoconstriction in rat aorta treated with lipopolysaccharide. $\mathrm{Br} J$ Pharmacol 1998, 125(2):327-334

28. Chiou WF, Chen CF, Lin JJ: Mechanisms of suppression of inducible nitric oxide synthase (iNOS) expression in Raw264.7 cells by andrographolide. Br J Pharmacol 2000, 129:1553-1560.

29. Shen YC, Chen CF, Chiou WF: Andrographolide prevents oxygen radical production by human neutrophils: possible mechanism(s) involved in its anti-inflammatory effect. Br J Pharmaco/ 2002, 135(2):399-406.

30. Tsai HR, Yang LM, Tsai WJ, Chiou WF: Andrographolide acts through inhibition of ERK $1 / 2$ and Akt phosphorylation to suppress chemotactic migration. Eur J Pharmacol 2004, 498(1-3):45-52

31. Xia YF, Ye BQ, Li YD, Wang JG, He XJ, Lin X: Andrographolide attenuates inflammation by inhibition of NF-KB activation through covalent modification of reduced cysteine 62 of p50. J Immunol 2004, 173:4207-4217

32. Hidalgo MA, Romero A, Figueroa J, Cortes P, Concha II, Hancke JL, Burgos RA: Andrographolide interferes with binding of nuclear factor- $\mathrm{KB}$ to DNA in HL-60-derived neutrophilic cells. Br J Pharmacol 2005, 144:680-686.

33. Qin LH, Kong L, Shi GJ, Wang ZT, Ge BX: Andrographolide inhibits the production of TNF- $\alpha$ and IL-12 in LPS stimulated macrophages: role of mitogen activated protein kinases. Biol Pharm Bull 2006, 29:220-224.

34. Batkhuu J, Hattori K, Takano F, Fushiya S, Oshiman Kl, Fujimiya Y: Suppression of NO production in activated macrophages in vitro and ex vivo by neoandrographolide isolated from Andrographis paniculata. Biol Pharm Bull 2002, 25:1169-1174

35. Liu J, Wang ZT, Ji LL, Ge BX: Inhibitory effects of neoandrographolide on nitric oxide and prostaglandin $\mathrm{E}_{2}$ production in LPS-stimulated murine macrophage. Mol Cell Biochem 2007, 298:49-57.

36. Liu J, Wang ZT, Ji LL: In vivo and in vitro anti-inflammatory activities of Neoandrographolide. Am J Chin Med 2007, 35:317-328.

37. Liu J, Wang ZT, Ge BX: Andrograpanin, isolated from Andrographis paniculata, exhibits anti-inflammatory property in lipopolysaccharide induced macrophage cells through down regulating the p38 MAPKs signaling pathways. Int Immunopharmacol 2008, 8:951-958.

38. Chao WW, Kuo YH, Lin BF: Construction of promoters based immunity screening system and its application on the study of traditional Chinese medicine herbs. Taiwanese J Agric Chem Food Sci 2007, 45:193-205

39. Chao WW, Kuo YH, Hsieh SL, Lin BF: Inhibitory effects of ethyl acetate extract of Andrographis paniculata on NF-KB trans-activation activity and LPS-induced acute inflammation in mice. Evid Based Complement Alternat Med 2009. doi:10.1093/ecam/nep120

40. Suebsasana S, Pongnaratorn P, Sattayasai J, Arkaravichien T, Tiamkao S, Aromdee C: Analgesic, antipyretic, anti-inflammatory and toxic effects of andrographolide derivatives in experimental animals. Arch Pharm Res 2009, 32(9):1191-1200.

41. Kumar RA, Sridevi K, Kumar NV, Nanduri S, Rajagopal S: Anticancer and immunostimulatory compounds from Andrographis paniculata. Ethnopharmacol 2004, 92:291-295.

42. Geethangili M, Rao YK, Fang SH, Tzeng YM: Cytotoxic constituents from Andrographis paniculata induce cell cycle arrest in Jurkat cells. Phytother Res 2008, 22:1336-1341.

43. Sheeja K, Kuttan G: Activation of cytotoxic T lymphocyte responses and attenuation of tumor growth in vivo by Andrographis paniculata extract and andrographolide. Immunopharmacol Immunotoxicol 2007, 29:81-93.

44. Chen L, Zhu H, Wang R, Zhou K, Jing Y, Qiu F: ent-Labdane diterpenoid lactone stereoisomers from Andrographis paniculata. J Nat Prod 2008, 71:852-855

45. Rajagopal S, Kumar RA, Deevi DS, Satyanarayana C, Rajagopalan R: Andrographolide, a potential cancer therapeutic agent isolated from Andrographis paniculata. J Exp Ther Oncol 2003, 3:147-158.

46. Satyanarayana C, Deevi DS, Rajagopalan R, Srinivas N, Rajagopal S: DRF3188 a novel semi-synthetic analog of andrographolide: cellular response to MCF 7 breast cancer cells. BMC cancer 2004, 4:26-33. 
47. Jada SR, Suseno GS, Matthews C, Hamzah AS, Lajis NH, Saad MS, Stevens MFG, Stanslas J: Semisynthesis and in vitro anticancer activities of andrographolide analogues. Phytochemistry 2007, 68:904-912.

48. Shi MD, Lin HH, Lee YC, Chao JK, Lin RA, Chen JH: Inhibition of cell-cycle progression in human colorectal carcinoma Lovo cells by andrographolide. Chem Biol Interact 2008, 174:201-210.

49. Cheung HY, Cheung SH, Li J, Cheung CS, Lai WP, Fong WF, Leung FM: Andrographolide isolated from Andrographis paniculata induces cell cycle arrest and mitochondrial mediated apoptosis in human leukemic HL-60 cells. Planta Med 2005, 71:1106-1111.

50. Ji L, liu T, Liu J, Chen Y, Wang Z: Andrographolide inhibits human hepatoma derived Hep3B cell growth through the activation of c-Jun N-terminal kinase. Planta Med 2007, 73:1397-1401.

51. Manikam SD, Stanslas J: Andrographolide inhibits growth of acute promyelocytic leukaemia cells by inducing retinoic acid receptorindependent cell differentiation and apoptosis. J Pharm Pharmacol 2009, 61(1):69-78

52. Zhou J, Zhang S, Ong CN, Shen HM: Critical role of pro-apoptotic BCl-2 family members in andrographolide induced apoptosis in human cancer cells. Biochem Pharmacol 2006, 72:132-144.

53. Zhou J, Lu GD, Ong CS, Ong CN, Shen HM: Andrographolide sensitizes cancer cells to TRAIL-induced apoptosis via p53 mediated beath receptor 4 up-regulation. Mol Cancer Ther 2008, 7(7):2170-2180.

54. Yang L, Wu D, Luo K, Wu S, Wu P: Andrographolide enhances 5fluorouracil induced apoptosis via caspase 8 dependent mitochondrial pathway involving p53 participation in hepatocellular carcinoma (SMMC-7721) cells. Cancer Lett 2009, 276:180-188.

55. Liang FP, Lin CH, Kuo CD, Chao HP, Fu SL: Suppression of v-SrC transformation by andrographolide via degradation of the $\mathrm{v}-\mathrm{Src}$ protein and attenuation of the Erk signaling pathway. J Bio/ Chem 2008, 283(8):5023-5033

56. Sheeja K, Guruvayoorappan C, Kuttan G: Antiangiogenic activity of Andrographis paniculata extract and andrographolide. Int Immunopharmacol 2007, 7:211-221.

57. Jiang CG, Li JB, Liu FR, WU T, Xu HM: Andrographolide inhibits the adhesion of gastric cancer cells to endothelial cells by blocking $\mathrm{E}-$ selectin expression. Anticancer Res 2007, 27:2439-2448.

58. Shi MD, Lin HH, Chiang TA, Tsai LY, Tsai SM, Lee YC, Chen JH: Andrographolide could inhibit human colorectal carcinoma Lovo cells migration and invasion via down regulation of MMP-7 expression. Chem Biol Interact 2009, 180:344-352.

59. Lee $\mathrm{YC}$, Lin $\mathrm{HH}$, Hsu CH, Wang $\mathrm{CJ}$, Chiang TA, Chen JH: Inhibitory effects of andrographolide on migration and invasion in human non-small cell lung cancer A549 cells via down-regulation of PI3K/Akt signalling pathway. Eur J Pharmacol 2010, 632(1-3):23-32.

60. Nanduri S, Nyavanandi VK, Thunuguntla SSR, Kasu S, Pallerla MK, Ram PS, Rajagopal S, Kumar RA, Ramanujam R, Babu JM, Vyas K, Devi AS, Reddy G $O$, Akella V: Synthesis and structure-activity relationships of andrographolide analogues as novel cytotoxic agents. Bioorganic Medicinal Chemistry Letters 2004, 14:4711-4717.

61. Rodríquez-Fernández E, Manzano JL, Alonso A, Almendral MJ, PérezAndrés M, Orfao A, Criado JJ: Fluorescent cisplatin analogues and cytotoxic activity. Curr Med Chem 2009, 16(32):4314-4327.

62. Jada SR, Matthews C, Saad MS, Hamzah AS, Lajis NH, Stevens MFG, Stanslas J: Benzylidene derivatives of andrographolide inhibit growth of breast and colon cancer cells in vitro by inducing G1 arrest and apoptosis. Br J Pharmacol 2008, 155:641-654

63. Zhou J, Ong CN, Hur GM, Shen HM: Inhibition of the JAK-STAT3 pathway by andrographolide enhances chemo-sensitivity of cancer cells to doxorubicin. Biochem Pharmacol 2010, 79(9):1242-1250.

64. Mosmann TR, Sad S: The expanding universe of T-cell subset: Th1, Th2 and more. Immunol Today 1996, 17:138-146.

65. Sheeja K, Kuttan G: Modulation of natural killer cell activity, antibodydependent cellular cytotoxicity, and antibody-dependent complement-mediated cytotoxicity by andrographolide in normal and Ehrlich ascites carcinoma-bearing mice. Integr Cancer Ther 2007 , 6(1):66-73.

66. Burgos RA, Seguel K, Perez M, Meneses A, Ortega M, Guarda MI, Loaiza A Hancke JL: Andrographolide inhibits IFN-gamma and IL-2 cytokine production and protects against cell apoptosis. Planta Med 2005, 71(5):429-434
67. Carretta MD, Alarcon P, Jara E, Solis L, Hancke JL, Concha II, Hidalgo MA, Burgos RA: Andrographolide reduces IL-2 production in T-cells by interfering with NFAT and MAPK activation. Eur J Pharmacol 2009, 602:413-421.

68. Iruretagoyena MI, Tobar JA, Gonzalez PA, Sepulveda SE, Figueroa CA, Burgos RA, Hancke JL, Kalergis AM: Andrographolide interferes with T cell activation and reduces experimental autoimmune encephalomyelitis in the mouse. J Pharmacol Exp Ther 2005, 312:366-372.

69. Li J, Luo L, Wang X, Liao B, Li G: Inhibition of NF-kB expression and allergen-induced airway inflammation in a mouse allergic asthma model by andrographolide. Cell Mol Immunol 2009, 6(5):381-385

70. Wang T, Liu B, Zhang W, Wilson B, Hong JS: Andrographolide reduces inflammation-mediated dopaminergic neurodegeneration in mesencephalic neuron-glia cultures by inhibiting microglial activation. J Pharmacol Exp Ther 2004, 308:975-983.

71. Bao Z, Guan S, Cheng C, Wu S, Wong SH, Kemeny DM, Leung BP, Wong WSF: A novel anti-inflammatory role for andrographolide in asthma via inhibition of the nuclear factor-kB pathway. Am J Respir Crit Care Med 2009, 179:657-665.

72. Abu-Ghefreh AA, Canatan H, Ezeamuzie Cl: In vitro and in vivo antiinflammatory effects of andrographolide. Int Immunopharmacol 2009, 9:313-318.

73. Burgos RA, Hancke JL, Bertoglio JC, Aguirre V, Arriagada S, Calvo M, Caceres DD: Efficacy of an Andrographis paniculata composition for the relief of rheumatoid arthritis symptoms: a prospective randomized placebo controlled trial. Clin Rheumatol 2009, 28:931-946.

74. Puri A, Saxena R, Saxena RP, Saxena KC, Srivastava V, Tandon JS: Immunostimulant agents from Andrographis paniculata. I Nat Prod 1993, 56(7):995-999

75. Panossian A, Davtyan T, Gukassyan N, Gukasova G, Mamikonyan G Gabrielian E, Wikman G: Effect of andrographolide and Kan Jang--fixed combination of extract SHA-10 and extract SHE-3 on proliferation of human lymphocytes, production of cytokines and immune activation markers in the whole blood cells culture. Phytomedicine 2002, 9(7):598-605.

76. Xu Y, Chen A, Fry S, Barrow RA, Marshall RL, Mukkur TKS: Modulation of immune response in mice immunized with an inactivated Salmonella vaccine and gavaged with Andrographis paniculata extract or andrographolide. Int Immunopharmacol 2007, 7:515-5238.

77. Naik SR, Hule A: Evaluation of immunomodulatory activity of an extract of Andrographolides from Andrographis paniculata. Planta Med 2009, 75:785-791.

78. Chang RS, Yeung HW: Inhibition of growth of human immunodeficiency virus in vitro by crude extracts of Chinese medicinal herbs. Antiviral Res 1988, 9:163-176.

79. Reddy VL, Reddy SM, Ravikanth V, Krishnaiah P, Goud TV, Rao TP, Ram TS Gonnade RG, Bhadbhade M, Venkateswarlu Y: A new bisandrographolide ether from Andrographis paniculata nees and evaluation of anti-HIV activity. Nat Prod Res 2005, 19:223-230.

80. Calabrese C, Berman SH, Babish JG, Ma X Shinto L, Dorr M, Well K Wenner CA, Standish LJ: A phase I trial of andrographolide in HIV positive patients and normal volunteers. Phytother Res 2000, 14:333-338

81. Wiart C, Kumar K, Yusof MY, Hamimah H, Fauzi ZM, Sulaiman M: Antiviral properties of ent-labdene diterpenes of Andrographis paniculata Nees, inhibitors of herpes simplex virus type I. Phytother Res 2005, 19:1069-1070

82. Lin TP, Chen SY, Duh PD, Chang LK, Liu YN: Inhibition of the Epstein-barr virus lytic cycle by andrographolide. Biol Pharm Bull 2008, 31(11):2018-2023.

83. Chen JX, Xue HJ, Ye WC, Fang BH, Liu YH, Yuan SH, Yu P, Wang YQ: Activity of andrographolide and its derivatives against influenza virus in vivo and in vitro. Biol Pharm Bull 2009, 32(8):1385-1391.

84. Jiang X, Yu P, Jiang J, Zhang Z, Wang Z, Yang Z, Tian Z, Wright SC, Larrick $J W$, Wang Y: Synthesis and evaluation of antibacterial activities of andrographolide analogues. Eur J Med Chem 2009, 44:2936-2943.

85. Gabrielian ES, Shukarian AK, Goukasova Gl, Chandanian GL, Panossian AG, Wikman G, Wagner H: A double blind, placebo-controlled study of Andrographis paniculata fixed combination Kan Jang in the treatment of acute upper respiratory tract infections including sinusitis. Phytomedicine 2000, 9(7):589-597. 
86. Ko HC, Wei BL, Chiou WF: The effect of medicinal plants used in Chinese folk medicine on RANTES secretion by virus infected human epithelial cells. J Ethnopharmacol 2006, 107:205-210.

87. Ji LL, Wang Z, Dong F, Zhang WB, Wang ZT: Andrograpanin, a compound isolated from anti-inflammatory traditional Chinese medicine Andrographis paniculata, enhances chemokine SDF-1a-induced leukocytes chemotaxis. J Cell Biochem 2005, 95:970-978.

88. Basak A, Cooper S, Roberge AG, Banik UK, Chretien M, Seidah NG: Inhibition of proprotein convertases-1,-7 and furin by diterpines of Andrographis paniculata and their succinoyl esters. Biochem J 1999, 338:107-113.

89. Chang RS, Ding L, Chen GQ, Pan QC, Zhao ZL, Smith KM: Dehydroandrographolide succinic acid monoester as an inhibitor against the human immunodeficiency virus. Proc Soc Exp Bio/ Med 1991, 197(1):59-66.

90. Singha PK, Roy S, Dey S: Protective activity of andrographolide and arabinogalactan proteins from Andrographis paniculata Nees. against ethanol induced toxicity in mice. J Ethnopharmacol 2007, 111:13-21.

91. Kapil A, Koul IB, Banerjee SK, Gupta BD: Antihepatotoxic effects of major diterpenoid constituents of Andrographis paniculata. Biochem Pharmacol 1993, 46(1):182-185.

92. Das S, Neogy S, Gautam N, Roy S: In vitro nitotine induced superoxide mediated DNA fragmentation in lymphocytes: protective role of Andrographis paniculata Nees. Toxicol in Vitro 2009, 23:90-98.

93. Das S, Gautam N, Dey SK, Maiti T, Roy S: Oxidative stress in the brain of nicotine induced toxicity: protective role of Andrographis paniculata Nees and vitamin E. Appl Physiol Nutr Metab 2009, 34:125-135.

94. Akowuah GA, Zhari I, Mariam A, Yam MF: Absorption of andrographolides from Andrographis paniculata and its effect on CCI(4)-induced oxidative stress in rats. Food Chem Toxicol 2009, 47(9):2321-2326.

95. Jaruchotikamol A, Jarukamiorn K, Sirisangtrakul W, Sakuma T, Kawasaki Y Nemoto N: Strong synergistic induction of CYP1A1 expression by andrographolide plus typical CYP1A inducers in mouse hepatocytes. Toxicol Appl Pharmacol 2007, 224:156-162.

96. Chatuphonprasert W, Jarukamjorn K, Kondo S, Nemoto N: Synergistic increases of metabolism and oxidation reduction genes on their expression after combined treatment with a CYP1A inducer and andrographolide. Chem Biol Interact 2009, 182:233-238.

97. Pekthong D, Martin H, Abadie C, Bonet A, Heyd B, Mantion G, Richert L: Differential iknhibition of rat and human hepatic cytochrome $\mathrm{P} 450$ by Andrographis paniculata extract and andrographolide. $J$

Ethnopharmacol 2008, 115:432-440.

98. Pekthong D, Blanchard N, Abadie C, Bonet A, Heyd B, Mantion G, Berthelot A, Richert L, Martin H: Effects of Andrographis paniculata extract and andrographolide on hepatic cytochrome P450 mRNA expression and monooxygenase activities after in vivo administration to rats and in vitro in rat and human hepatocyte cultures. Chem Biol Interact 2009, 179:247-255.

99. Chang KT, Lii CK, Tsai CW, Yang AJ, Chen HW: Modulation of the expression of the $\pi$ class of glutathione S-transferase by Andrographis paniculata extracts and andrographolide. Food Chem Toxicol 2008, 46:1079-1088

100. Yang AJ, Li CC, Lu CY, Liu KL, Tsai CW, Lii CK, Chen HW: Activation of the CAMP/CREB/inducible CAMP early repressor pathway suppresses andrographolide-induced gene expression of the $\pi$ class of glutathione S-transferase in rat primary hepatocytes. J Agric Food Chem 2010, 58:1993-2000

101. Zhang CY, Tan BK: Hypotensive activity of aqueous extract of Andrographis paniculata in rats. Clin Exp Pharmacol Physiol 1996, 23:675-678.

102. Zhang CY, Tan BK: Mechanism of cardiovascular acrivity of Andrographis paniculata in the anaesthetized rat. JEthnopharmacol 1997, 56:97-101.

103. Zhang CY, Tan BK: Vasorelaxation of rat thoracic aorta caused by $14-$ deoxyandrographolide. Clin Exp Pharmacol Physiol 1998, 25:424-429.

104. Zhang C, Kuroyangi M, Tan BK: Cardiovascular activity of 14-deoxy11,12-didehydroandrographolide in the anaesthetized rat and isolated right atria. Pharmacol Res 1998, 38(6):413-417.

105. Zhang CY, Tan BK: Effects of 14-deoxyandrographolide and 14-deoxy11,12-didehydroandrographolide on nitric oxide production in cultured human endothelial cells. Phytother Res 1999, 13:157-159.
106. Burgos RA, Loyola M, Hidalgo MA, Labranche TP, Hancke JL: Effects of 14deoxyandrographolide on calcium mediated rat uterine smooth muscle vontractility. Phytother Res 2003, 17:1011-1015

107. Yoopan N, Thisoda P, Rangkadilok N, Sahasitiwat S, Pholphana N, Ruchirawat S: Cardiovascular effects of 14-deoxy-11,12didehydroandrographolide and Andrographis paniculata extracts. Planta Med 2007, 73:503-511.

108. Chen JH, Hsiao G, Lee AR, Wu CC, Yen MH: Andrographolide suppresses endothelial cell apoptosis via activation of phosphatidyl inositol-3kinase/Akt pathway. Biochem Pharmacol 2004, 67:1337-1345.

109. Thisoda P, Rangkadilok N, Pholphana N, Worasuttayangkurn L, Ruchirawat S, Satayavivad J: Inhibitory effect of Andrographis paniculata extract and its active diterpenoids on platelet aggregation. Eur J Pharmacol 2006, 553:39-45.

110. Wu TS, Chern HJ, Damu AG, Kuo PC, Su CR, Lee EJ, Teng CM: Flavonoids and ent-labdane diterpenoids from Andrographis paniculata and their antiplatelet aggregatory and vasorelaxing effects. J Asian Nat Prod Res 2008, 10(1-2):17-24

111. Hui H, Tang G, Go VLW: Hypoglycemic herbs and their action mechanisms. Chin Med 2009, 4:11-14.

112. Zhang XF, Tan BK: Anti-diabetic property of ethanolic extract of Andrographis paniculata in streptozotocin-diabetic rats. Acta Pharmacol Sin 2000, 21(12):1157-1164.

113. Zhang XF, Tan BK: Antihyperglycaemic and anti-oxidant properties of Andrographis paniculata in normal and diabetic rats. Clin Exp Pharmacol Physiol 2000, 27:358-363.

114. Subramanian R, Asmawi MZ, Sadikun A: In vitro alpha-glucosidase and alpha-amylase enzyme inhibitory effects of Andrographis paniculata extract and andrographolide. Acta Biochim Pol 2008, 55(2):391-398.

115. Husen R, Pihie AH, Nallappan M: Screening for antihyperglycaemic activity in several local herbs of Malaysia. J Ethnopharmacol 2004, 95(23):205-208.

116. Reyes BA, Bautista ND, Tanquilut NC, Anunciado RV, Leung AB, Sanchez GC, Magtoto RL, Castronuevo P, Tsukamura H, Maeda Kl: Anti-diabetic potentials of Momordica charantia and Andrographis paniculata and their effects on estrous cyclicity of alloxan-induced diabetic rats. $J$ Ethnopharmacol 2006, 105(1-2):196-200.

117. Yu BC, Hung CR, Chen WC, Cheng JT: Antihyperglycemic effect of andrographolide in streptozotocin induced diabetic rats. Planta Med 2003, 69:1075-1079

118. Yu BC, Chang CK, Su CF, Cheng JT: Mediation of $\beta$-endorphin in andrographolide induced plasma glucose lowering action in type I diabetes like animals. Naunyn-Schmiedeberg's Arch Pharmacol 2008, 377:529-540.

119. Zhang Z, Jiang J, Yu P, Zeng X, Larrick JW, Wang Y: Hypoglycemic and beta cell protective effects of andrographolide analogue for diabetes treatment. J Translational Med 2009, 7:62-73.

120. Kamdem RE, Sang S, Ho CT: Mechanism of the superoxide scavenging activity of Neoandrographolide a natural product from Andrographis paniculata Nees. J Agric Food Chem 2002, 50:4662-4665.

121. Singh RP, Banerjee S, Rao AR: Modulatory influence of Andrographis paniculata on mouse hepatic and extrahepatic carcinogen metabolizing enzymes and antioxidant status. Phytother Res 2001 15:382-390

122. Akowuah GA, Zhari I, Mariam A: Analysis of urinary andrographolides and antioxidants after oral administration of Andrographis paniculata leaf extract in rats. Food Chem Toxicol 2008, 46:3616-3620.

123. Verma N, Vinayak M: Antioxidant action of Andrographis paniculata on lymphoma. Mol Biol Rep 2008, 35:535-540.

124. Lin FL, Wu SJ, Lee SC, Ng LT: Antioxidant, antioedema and analgesic activities of Andrographis paniculata extracts and their active constituent andrographolide. Phytother Res 2009, 23:958-964.

doi: $10.1186 / 1749-8546-5-17$

Cite this article as: Chao and Lin, Isolation and identification of bioactive compounds in Andrographis paniculata (Chuanxinlian) Chinese Medicine 2010, 5:17 